\title{
Gender and Adaptation Practices to the Effects of Climate Change in Bahi and Kondoa Districts Dodoma Region, Tanzania
}

\author{
Okuli W. Swai ${ }^{1}$, Jonathan S. Mbwambo ${ }^{2}$ \& Flavianus T. Magayane ${ }^{3}$ \\ ${ }^{1}$ Department of Development Studies, School of Social Sciences, University of Dodoma, Dodoma, Tanzania \\ ${ }^{2}$ Development Studies Institute, Sokoine University of Agriculture, Morogoro, Tanzania \\ ${ }^{3}$ Agricultural Education and Extension, Sokoine University of Agriculture, Morogoro, Tanzania \\ Correspondence: Department of Development Studies, School of Social Sciences, University of Dodoma, P.O. \\ Box 1073, Dodoma, Tanzania. Tel: 255-714-206-782. E-mail:okuliwilly@yahoo.com
}

Received: October 11, 2012 Accepted: November 16, 2012 Online Published: November 29, 2012

doi:10.5539/jsd.v5n12p65 URL: http://dx.doi.org/10.5539/jsd.v5n12p65

\begin{abstract}
Climate change has different effects between men and women, but disaggregated data by gender to realize specific adaptation practices undertaken by men and women in Tanzania are scarce. To fill part of the information gap, this study analyzed adaptation practices to the effects of climate change by gender in Bahi and Kondoa Districts Dodoma region, Tanzania. The study also analyzed perception of climate change and identified elements influencing adaptation practices. A sample of 360 respondents, 12 focus groups of discussants and 78 key informants were consulted. Analysis involved descriptive statistics for quantitative data and content analysis for qualitative data. Results showed that women were more devoted to adaptation practices that enabled them to adapt to or reduce hunger/food, water and firewood shortages while men were more devoted to adaptation practices that enabled them to adapt to or reduce effects of climate change on crops, livestock and environment. The corrected Rao-Scott chi-square $\left(\chi_{c}^{2}\right)$ test showed significant association between adaptation practices implemented by respondents and sex, revealing that undertaken adaptation practices varied by sex. Respondents perceived climate change and managed to identify adaptation practices undertaken to manage climate change effects. The findings can be used to improve/formulate appropriate adaptation practices to manage climate change problems in agriculture sector. The study recommends systematic collection of in-depth information of this kind at the community level in other areas of Dodoma Region, Tanzania and the LDCs in order for the policy makers to design and implement appropriate interventions to manage climate change problems.
\end{abstract}

Keywords: climate change, gender, agricultural production, adaptation practices

\section{Introduction}

Despite the fact that climate change has different effects between men and women, disaggregated data by gender to realize specific adaptation practices undertaken by men and women are scarce. Climate change literature indicates that effects of climate change including variation in temperature and rainfall, drought, floods, heat waves, hurricanes and typhoons have already occurred across the world; affecting countries, income groups and occupations differently (Chaudhary \& Aryal, 2009; Intergovernmental Panel on Climate Change [IPCC], 2007). The negative effects of climate change are more severe in sub-Saharan Africa, including Tanzania (Cline, 2007; Haque, Yamamoto, \& Sauerborn, 2012). Tanzania is experiencing greater weather extremes including increases in temperature and changes in rainfall patterns. Such effects have increased drought, floods, land resources degradation as well as health problems. The intensity of droughts, floods and changes to growing seasons have significant effects on agricultural productivity, water supply, food security and human welfare (Yanda, Kangalawe, \& Sigalla, 2006; United Republic of Tanzania [URT], 2007). For example, the drought that occurred in 2005/06 and the El Niño in 1997/98, highlight the country's vulnerability to current climatic hazards (Ehrhart \& Twena, 2006). Moreover, Dodoma region in Tanzania is among the regions severely affected by failing agriculture due to climate change, as the region is situated in semi-arid areas (Food and Agricultural Organization [FAO], 2008).

Although all small-holder farmers in Dodoma region will be affected by climate change, women are expected to be severely affected because in addition to extreme poverty and low adaptive capacity, they make up a large 
number of individuals working in agricultural production. In addition, inequalities existing between men and women partly due to statutory and/or customary laws that often restrict women's property and land rights; constrain women from accessing important resources for example, land and credit, undermining further their adaptive capacity (Osman-Elasha, 2008; Brody, Demetriades, \& Esplen, 2008). The fact that women are likely to be more affected by climate change is also supported by climate change literature insisting studies focusing on gender and climate change to be conducted at community level in order to gather disaggregated data (Lambrou \& Piana, 2006; United Nations Population Fund [UNFPA], 2009; United Nation Development Programme [UNDP], 2009).

It is obvious that people in drought and flood-affected communities have evolved their own adaptation strategies to protect their families, assets and secure food security (Agrawal, McSweeney, \& Perrin, 2008; Odjugo, 2010). Moreover, previous studies by various scholars, including Maddison (2006), Ishaya and Abaje (2008), Paavola (2008), Mutekwa (2009) and Lema and Majule (2009) have reported farmer observations of climate change and existing adaptation strategies for managing climate risks, for example, proper timing of agricultural operations and use of different crop varieties. Nevertheless, the findings are not disaggregated by gender to realize specific adaptation practices undertaken by men and women. Moreover, studies focusing on gender and adaptation to the effects of climate change have been conducted in developing countries for example, Agwu and Okhimamhe (2009), Ribeiro and Chaúque (2010) and Kapoor (2011) but in Tanzania studies focusing on gender and climate change are scarce.

Lack of disaggregated data has meant that policy makers dealing with climate change in Tanzania including the National Adaptation Program of Action (NAPA) cannot come up with effective policies or adaptation options. According to UNFPA (2009) and UNDP (2009), for the policy that is intended to address any aspect of climate change to be effective, the differences between men, women, boys and girls must be taken into account during policy formulation. Gender blind policies may exacerbate the problems associated with climate change by widening inequalities between the sexes. Thus, to attain effective and successful adaptation, the needs of men and women should be integrated in adaptation plans and policies. This can only be achieved if information on how men and women are adapting to climate change effects will be gathered. This paper intends to fill part of this gap of information by analyzing adaptation practices to the effects of climate change by gender in Bahi and Kondoa Districts of Dodoma Region. The rest of the paper is structured as follows: it starts with methodology section which includes the study area, methods of data collection and data analysis; then the results and discussions section; and finally recommendations and the conclusion section.

\section{Methodology}

\subsection{Study Area}

The study was conducted in three villages of Bahi District, Dodoma Region, namely Nagulobahi, Chipanga B and Msisi; and three villages of Kondoa District that is Puhi, Isusumya and Kurio. Administratively Bahi District has four divisions, 21 wards and 56 villages whereas Kondoa District has eight divisions, 35 wards and 160 villages. Both Districts are situated in semi-arid areas and have a dry savannah type of climate, which is characterized by long dry season, unimodal and erratic rainfall that falls between November/December and April. Bahi District has an annual average rainfall of about 500 to $700 \mathrm{~mm}$ and annual average temperature of about $22.6^{\circ} \mathrm{C}$. Kondoa District has an annual average rainfall of about 500 to $800 \mathrm{~mm}$ and an annual temperature of about $21^{\circ} \mathrm{C}$. The economies of Bahi and Kondoa Districts depend on agriculture (crops and livestock production). The main crops grown in Bahi District are pearl millet, sorghum, paddy and ground nuts; and for Kondoa District the main crops are maize, finger millet, oil seeds, pearl millet and sorghum (URT, 2003).

\subsection{Research Design and Methods of Data Collection}

The study employed a cross-sectional research design and both primary and secondary data were collected. Primary data involved qualitative and quantitative data. The study sample was obtained by using simple random sampling technique from a sampling frame of farmers who were dealing with crop production and livestock keeping. Moreover, key informants involved purposive selected ward and village leaders, crops and livestock extension workers, religious leaders, members of village government committees, head teachers and elderly farmers (two men and two women). Methods to collect qualitative data involved key informant interviews and focus group discussions; and a structured questionnaire was used to collect quantitative data. To collect qualitative data, a checklist of items for an in-depth interview with key informants was used to gather information from 78 key informants; and a focus group interview guide was used in discussion to gather information from 12 focus groups (one group of men and one of women from each village). To collect quantitative data, a structured questionnaire was administered to a sample of 360 respondents (30 men and 30 
women from each village) to verify and quantify some of the findings from qualitative data. Secondary data were gathered from various reports relevant to the study and the web.

\subsection{Data Analysis}

Analysis of qualitative data was done by using content analysis in which the data were broken down into smallest meaningful units of information and/or themes and summarized to supplement important information with respect to the objectives of the study. Quantitative data analysis was based mainly on descriptive statistics including frequencies, means, percentages and cross-tabulations. Perception on climate change was measured by using indices of four climate change indicators (increased rainfall variation i.e. increased rainfall unpredictability and irregularity; increased temperature; strong wind; and drought) formed from Likert items (Marshall \& Marshall, 2007). Inferential analysis involved chi-square test at $p<0.05$ level of significance, employed to determine association between the variables; and corrected Rao-Scott chi-square $\left(\chi_{c}{ }^{2}\right)$ that was used to determine association between variables for the multiple response answers (Lavassani, Movahedi, \& Kumar, 2009).

\section{Results and Discussions}

\subsection{Demographic and Socio-economic Characteristics of Respondents}

\subsubsection{Mean Age and Family Size}

Results in Table 1 show that the average age of respondents was 54.0 years for men and 50.0 years for women. The average number of years of engagement in crop production was 35.0 for men and 32.0 for women while for the case of livestock keeping was 19.0 years for men and 16.0 years for women. It is further shown in Table 1 that the family size of respondents was 7.0 members for men and 6.0 for women. Family sizes in both cases were large and above the rural average household size of 5.1 (URT, 2002). Large family sizes are an important asset in working together to reduce vulnerability to the effects of climate change. This occurs when almost all of the household members take part in production and/or service provision to contribute to the economy of the household (Kayunze, 2000). Conversely, having big families is said to be one of the causes of poverty in Tanzania (URT, 2002).

Table 1. Mean age, years in crops and livestock production and family size

\begin{tabular}{lcc}
\hline Respondent characteristic & \multicolumn{2}{c}{ Mean } \\
& Men $(\mathbf{n}=\mathbf{1 8 0})$ & Women $(\mathbf{n}=\mathbf{1 8 0})$ \\
\hline Respondent age & 54.4 & 50.0 \\
Years in crop production & 35.0 & 32.0 \\
Years in livestock keeping & 19.0 & 16.0 \\
Family size & 7.0 & 6.0 \\
\hline
\end{tabular}

Source: Survey data (2011).

\subsubsection{Education Level}

Among the interviewed respondents $83.3 \%$ of men and $69.4 \%$ of women had attained primary school education level (Table 2). The number of women with primary school education level was half that of men, indicating that more men had attained primary education level compared to women. Although the Tanzania Human Development Report (2000) shows that the gap of education between men and women for primary level has been corrected, the changes may hold for the coming generation, but that gap still exists between men and women farmers for the earlier generation. Education is the source of knowledge which is very essential for respondents to perceive and interpret day to day changes experienced when interacting with climate. According to Prahalad (2009), education has a key role to play in promoting understanding and helping individuals and community to make informed choices to respond to challenges posed by climate change. 
Table 2. Distribution of respondents by education level

\begin{tabular}{lcccc}
\hline Respondent characteristic & \multicolumn{2}{c}{ Men $(\mathbf{n}=\mathbf{1 8 0})$} & \multicolumn{2}{c}{ Women (n=180) } \\
& $\mathbf{n}$ & $\mathbf{\%}$ & $\mathbf{n}$ & $\mathbf{\%}$ \\
\hline Education level of respondents & & & & \\
Primary school level & 150 & 83.3 & 125 & 69.4 \\
Adult education & 5 & 2.8 & 5 & 2.8 \\
Secondary school level & 1 & 0.6 & 0 & 0.0 \\
None (had not gone to school) & 24 & 3.3 & 50 & 27.8 \\
Total & $\mathbf{1 8 0}$ & $\mathbf{1 0 0 . 0}$ & $\mathbf{1 8 0}$ & $\mathbf{1 0 0 . 0}$ \\
\hline
\end{tabular}

Source: Survey data (2011).

\subsubsection{Land Acquisition}

The findings in Table 3 show that to acquire land $36.0 \%$ of men and $31.3 \%$ of women responses cleared the forest during village establishment; $29.4 \%$ of men and $33.5 \%$ of women responses inherited land from their parents; and $18.1 \%$ of men and $23.3 \%$ of women responses purchased the land. During village establishment in the 1970s, the land was abundant and farmers practiced shifting cultivation. However, as the population increased demand for land also increased such that, it was impossible for the farmers to expand the land freely within villages. To expand their farms farmers were forced to purchase land from their fellow farmers within the village or nearby villages. The mean hectares of land owned by respondents were 3.8 for men and 1.9 for women, indicating that the land size of women was only half of that owned by men. Having small farms was among the major obstacles that constrained respondents from planting on different dates; livestock keepers to spare a plot for livestock to graze during dry season; harvesting enough food; and was one of the causes of increased vulnerability for women to climate change. The same observation was also reported by Deressa, Hassan, Alemu, Yesuf and Ringler (2008).

Table 3. Distribution of respondents by land acquisition

\begin{tabular}{lcccc}
\hline Respondent characteristic & \multicolumn{2}{c}{$\begin{array}{c}\text { Men }(\mathbf{n}=\mathbf{1 8 0}) \\
\text { \% of responses }\end{array}$} & $\begin{array}{c}\text { Women }(\mathbf{n}=\mathbf{1 8 0}) \\
\text { Count }\end{array}$ & \begin{tabular}{l} 
\% of responses \\
\hline Land acquisition
\end{tabular} \\
Cleared the forest/bush & 131 & 36.0 & 100 & 31.3 \\
Inherited & 107 & 29.4 & 107 & 33.5 \\
Purchased & 66 & 18.1 & 42 & 23.3 \\
Others & 60 & 16.5 & 70 & 22.0 \\
Total & $\mathbf{3 6 4}$ & $\mathbf{1 0 0 . 0}$ & $\mathbf{3 1 9}$ & $\mathbf{1 0 0 . 0}$ \\
\hline
\end{tabular}

NB: Multiple responses.

Source: Survey data (2011).

\subsubsection{Production Activities Undertaken by Respondents}

It is seen in Table 4 that the main production activities undertaken by respondents were crop and livestock production $(78.9 \%$ of men and $50.0 \%$ of women). The findings further revealed that many men were agro-pastoralists compared to women, half of whom were crop producers; production activities that need enough rainfall in a changing climate. 
Table 4. Production activities undertaken by respondents

\begin{tabular}{lcccc}
\hline Production activities & \multicolumn{3}{c}{ Men $(\mathbf{n}=\mathbf{1 8 0})$} & \multicolumn{2}{c}{ Women $(\mathbf{n}=\mathbf{1 8 0})$} \\
& $\mathbf{n}$ & $\mathbf{\%}$ & $\mathbf{n}$ & $\mathbf{\%}$ \\
\hline The main production activities of men and women & & & & \\
Agro-pastoralists & 142 & 78.9 & 90 & 50.0 \\
Crop production & 38 & 21.1 & 90 & 50.0 \\
Total & $\mathbf{1 8 0}$ & $\mathbf{1 0 0 . 0}$ & $\mathbf{1 8 0}$ & $\mathbf{1 0 0 . 0}$ \\
\hline
\end{tabular}

Source: Survey data (2011).

\subsubsection{Ownership, access and control of household assets}

Assets owned by households were hand hoes, houses, land, local chickens, goats, cattle and ox-ploughs (Table 5). Spouses had access to household assets but men were the owners and they controlled all household assets; except for $32.8 \%$ of women, the majority of whom were widows (16.7\%), separated (5.6\%), divorced (4.4\%) and single (3.3\%). Limited control of the household assets is one of the causes of increased vulnerability for women to climate change (Brody et al., 2008; UNFPA, 2009).

Table 5. Access, Ownership and Control of Household Assets

\begin{tabular}{|c|c|c|c|c|}
\hline \multirow[t]{2}{*}{ Access and control of assets } & \multicolumn{2}{|c|}{$\operatorname{Men}(n=180)$} & \multicolumn{2}{|c|}{ Women $(n=180)$} \\
\hline & $\mathbf{n}$ & $\%$ & $\mathbf{n}$ & $\%$ \\
\hline \multicolumn{5}{|l|}{ Assets owned by respondent" } \\
\hline Hand hoes & 180 & 17.6 & 180 & 21.8 \\
\hline House & 180 & 17.6 & 176 & 21.3 \\
\hline Land & 179 & 17.5 & 164 & 19.8 \\
\hline Local chicken & 134 & 13.0 & 119 & 14.4 \\
\hline Goats & 104 & 10.2 & 59 & 7.1 \\
\hline Cattle & 75 & 7.3 & 34 & 4.1 \\
\hline Ox-ploughs & 68 & 6.6 & 33 & 4.0 \\
\hline Others & 104 & 10.2 & 62 & 7.5 \\
\hline Total & 1024 & 100.0 & 827 & 100.0 \\
\hline \multicolumn{5}{|c|}{ Respondent's level of control of household assets } \\
\hline Control all household assets & 180 & 100.0 & 59 & 32.8 \\
\hline Control hand hoe, axe and machetes & 0 & 0.0 & 40 & 22.2 \\
\hline All assets are controlled by my husband & 0 & 0.0 & 81 & 45.0 \\
\hline Total & 180 & 100.0 & 180 & 100.0 \\
\hline
\end{tabular}

NB: *Multiple responses.

Source: Survey data (2011).

\subsection{Perception of Climate Change by Sex}

Using the indices of Likert items based on the four climate change indicators (increased rainfall variation, temperature, strong wind and drought) it was revealed that $87.2 \%$ of men and $76.7 \%$ of women perceived the change in rainfall; $98.3 \%$ of men and $97.2 \%$ of women perceived the change in temperature; $97.2 \%$ of men and $95.6 \%$ of women perceived the change in strong wind; and all interviewed men and $98.9 \%$ of women perceived the change in drought. The results indicate that majority of men and women perceived changes in climate (Table 6). The chi-square test showed significant association between perception of respondents on the change in rainfall and $\operatorname{sex}\left(\chi^{2}=11.588 ; p \leq 0.05\right)$; the change in strong wind and village of respondent $\left(\chi^{2}=42.792 ; p \leq 0.01\right)$; 
the change in drought and marital status $\left(\chi^{2}=73.536 ; p \leq 0.001\right)$ and the change in drought and ethnic groups of respondents $\left(\chi^{2}=193.098 ; p \leq 0.001\right)$. The findings show that perception of climate change in the study area varied by sex, village of respondent, marital status and ethnic groups of respondents.

Table 6. Perception of respondents on climate change by sex

\begin{tabular}{lcccc}
\hline Scale for perception & \multicolumn{3}{c}{ Men $(\mathbf{n}=\mathbf{1 8 0})$} & \multicolumn{2}{c}{ Women $(\mathbf{n}=\mathbf{1 8 0})$} \\
& $\mathbf{n}$ & $\mathbf{\%}$ & $\mathbf{n}$ & $\mathbf{\%}$ \\
\hline Perception on increased rainfall variation & & & & \\
Perceiving & 157 & 87.2 & 138 & 76.7 \\
Not perceiving & 23 & 12.8 & 42 & 23.3 \\
Perception on increased temperature & & & & \\
Perceiving & 177 & 98.3 & 175 & 97.2 \\
Not perceiving & 3 & 1.7 & 5 & 2.8 \\
Perception on increased strong wind & & & & \\
Perceiving & 175 & 97.2 & 172 & 95.6 \\
Not perceiving & 5 & 2.8 & 8 & 4.4 \\
Perception on increased drought & & & & \\
Perceiving & 180 & 100.0 & 178 & 98.9 \\
Not perceiving & 0 & 0.0 & 2 & 1.1 \\
\hline
\end{tabular}

Source: Survey data (2011).

During focus group discussions and key informant interviews it was also revealed that bad years had increased and good years decreased in Bahi District since 1984 and 1990 in Kondoa District. The findings from the field related to the trend of anomalies of meteorological data from the Tanzania Meteorological Agency Dar es salaam for 1970 to 2010 period, which showed a significantly decrease in rainfall amount for the Bahi District from $1980 / 81$ (that is $\mathrm{R}^{2}=0.205, \mathrm{p} \leq 0.05$ ), a significantly increase in mean minimum and maximum temperatures (that is $\mathrm{R}^{2}=0.404, \mathrm{p} \leq 0.001$ and $\mathrm{R}^{2}=0.125, \mathrm{p} \leq 0.05$ respectively); and mean wind speed (that is $\mathrm{R}^{2}=0.276, \mathrm{p} \leq$ 0.01) for Dodoma Region. However, for Kondoa District rainfall amount had decreased insignificantly from $1984 / 85$ (that is $\mathrm{R}^{2}=0.022, \mathrm{p}=0.4628$ ), indicating that the area might be more affected by variations in rainfall onset and rainfall distribution than the change in rainfall amount. The findings also agreed with climate change literature and the findings of other scientists that showed/predicted increased temperature, drought (especially in semi-arid areas) and decreased precipitation in Tanzania and other areas of Africa (World Wide Fund for Nature [WWF], 2006; United Nations Framework for Conversion on Climate Change [UNFCCC], 2007; IPCC, 2007; Ishaya \& Abaje, 2008; Mongi, Majule, \& Lyimo, 2010; Nature, 2011; Haque et al., 2012).

\subsection{Perceived Effects of Climate Change in the Study Area}

In the study area climate change had damaged crops due to drought; reduced pastures, water and firewood; caused livestock deaths; reduced non-farm production activities; and was the main cause of persistent low yield. The consequences of perceived physical effects of climate change were increased food shortage/hunger and body weakness due to low food intake; persistent low income; waste of resources including money, labour, time and productive land; farmers being subjected to bad food debts; increased family conflict; out-migration; decreased sanitation and hygiene; waste of productive time in less productive activities; and reduced status. Similar findings were reported by various studies including Nelson and Stathers (2009), Mengistu (2011), Jotoafrica (2011), Swai, Mbwambo and Magayane (2012).

\subsection{Practices Undertaken to Adapt to or Reduce Effects of Climate Change}

\subsubsection{Practices Undertaken to Adapt to or Reduce Effects of Food Shortage or Hunger by Sex}

Findings in Table 7 show that in short term women were leading in reducing number of meals per day including quantity and quality of food (meal) for example, taking porridge instead of stiff porridge (ugali); feeding on wild fruits; and starving for a day or two. Women were also in the front line to embark on casual labour; non-farm 
production activities including petty trade and local brew; borrow food from traditional credit; and were assisted by relatives and friends. Conversely, men were in the front line to sell livestock, local chickens and other belongings including bicycles and radio; and to emigrate to various villages including Mpwayungu, Matui and Endasaki and also to Kondoa, Dodoma and Dar es Salaam towns to sell labour or exchange labour and various commodities for food (Swai et al., 2012). Emigration was opted when opportunities to get money or food were fading in the village. Men emigrated in groups and after obtaining food one of the group members brought food back home.

Table 7. Adaptation practices undertaken to adapt to or reduce effects of climate change

\begin{tabular}{lcccc}
\hline Adaptation practices & Men (n=180) & \multicolumn{2}{c}{ Women (n=180) } \\
\hline & Count & $\begin{array}{c}\text { \% of } \\
\text { responses }\end{array}$ & Count & $\begin{array}{c}\text { \% of } \\
\text { responses }\end{array}$ \\
\hline $\begin{array}{l}\text { Practices undertaken to adapt to or reduce effects of food } \\
\text { shortage or hunger }\end{array}$ & & & & \\
Reduce number of meals, wild fruits, starve & 165 & 13 & 172 & 11.3 \\
Sell labour, assisted by relatives/friends & 155 & 12.2 & 176 & 11.6 \\
Sell livestock and/or local chicken & 152 & 12 & 93 & 6.1 \\
Engage in non-farm production activities & 128 & 10.1 & 149 & 9.8 \\
Plant hunger buffering crops e.g. sweet potatoes & 120 & 9.5 & 145 & 9.6 \\
Emigrated & 108 & 8.5 & 33 & 2.2 \\
Borrowing food from traditional food credit & 98 & 7.7 & 129 & 8.5 \\
Practices undertaken to adapt to or reduce effects of & & & & \\
water and firewood shortages & & & & \\
Drill deep water wells & 143 & 11.3 & 2 & 0.1 \\
Fetch water/firewood from far sources; control/boil water & 93 & 7.3 & 180 & 11.9 \\
Sell food crops to buy water & 40 & 3.2 & 65 & 4.3 \\
Drill shallow water wells for domestic use & 3 & 0.2 & 165 & 10.9 \\
Use cobs, stalks, bricks stoves & 2 & 0.2 & 123 & 8.1 \\
Others & 60 & 4.7 & 86 & 5.7 \\
Total & $\mathbf{1 2 6 7}$ & $\mathbf{1 0 0}$ & $\mathbf{1 5 1 8}$ & $\mathbf{1 0 0}$ \\
\hline
\end{tabular}

NB: Multiple responses.

Source: Survey data (2011).

While men were away women, the majority $(81.7 \%)$ of who remained within the village, continued to search for casual labour and others undertake petty trade to save the family from hunger. Women sacrificed more of their time, energy and whatever they had, including their food share for the family members. Although it was their responsibility to keep enough seeds for the next season, women allowed family members to consume seeds during severe food shortage/hunger. To avoid wasting food they used rosella flowers, sugar and bicarbonate to make local brew instead of using cereals.

\subsubsection{Practices Undertaken to Adapt to or Reduce Effects of Water and Firewood Shortages by Sex}

It is also depicted in Table 7 that to adapt to or reduce effects of water shortage, women drilled shallow water wells which were mainly for domestic purpose; and men drilled deep water wells. When water shortage increased, especially after August, women were forced to awake early in the morning to fetch water from far water sources either within their village or at nearby villages. In the 1990s, men had joined women in fetching water and using bicycles or wheel barrows they could fetch up to six buckets of water per trip. Equally, respondents sold food crop products to buy water, especially in Isusumya village where the price per bucket of water ranged between TZS 500.00 and 700.00. Moreover, women were leading in boiling water especially 
during rain season to reduce contamination and water borne infectious diseases. They also controlled water use by reducing frequencies of bathing and washing, measures that reduced frequencies of fetching water.

To adapt to or reduce effects of firewood shortage, women used maize cobs and stalks of sorghum, pearl millet and maize for cooking; and in Puhi village potters were using energy serving stoves made of bricks which enabled them to use little quantities of firewood during pot processing (Table 7). Moreover, men had joined women in collecting firewood where they hired power tillers, ox-carts or tractors and went far in the forest to fell trees in order to collect firewood in greater quantities. For example, respondents from Nagulobahi village were collecting firewood from Uhelela village, a distance of seven kilometers. The firewood was then dried at home and could be used for more than three months. During week-ends and after classes women were accompanied by boys rarely and girls often to collect water and firewood. Agwu and Okhimamhe (2009) indicate the same findings. Firewood and water collection were the role of women in the 1970s, but it is shown in Table 7 that men were also collecting water and firewood in the 1990s; probably due to the long distance that women travelled and time spent in those activities in the 1990s.

Men engaging in collecting water and firewood show that their roles are changing, indicating further that the cultural division of labour demarcating gender constructed roles can no longer hold as climate change increases; as not only the role of men that had changed but, women were also engaged in emigration regardless of their marital status in the 1990s. The same observation was reported in Jotoafrika (2011). Measures undertaken by women to control water use, together with the assistance they were getting from men reduced frequencies of women to fetch water and firewood and enabled them to save time that could otherwise be wasted. It is evident from the findings in Table 7 that women were leading in most of practices to adapt to or reduce effects of food shortage/hunger, water and firewood shortages. The corrected Rao-Scott chi-square $\left(\chi_{c}^{2}\right)$ test showed significant association between the adaptation practices undertaken by respondents and $\operatorname{sex}\left(\chi_{c}{ }^{2}=1219.799 ; p \leq 0.001\right)$ revealing that undertaken adaptation practices varied by sex.

\subsubsection{Practices Undertaken to Adapt to or Reduce Effects of Climate Change on Production Activities by Sex}

Results in Table 8 show that to adapt to or reduce effects of climate change on livestock, men were in the front line to feed livestock tree leaves for example, miyombo and sausage tree (mwegea) every season; and banana stems especially in Puhi village. As pasture and water decreased herders moved livestock to areas that were less affected by drought. For example, herders from Isusumya village moved livestock to Zajirwa and Izava villages, a journey which took 20 hours. This was a long journey that herders could not travel every day. Instead they travelled after every three days forcing livestock to go without water for three days, as one of the adaptation measures. In addition, respondents spared a plot during cropping season for livestock to graze on during dry season; preserved grasses and crop residues for livestock to feed during pasture shortages; sold livestock to reduce them to a manageable number; and loaned livestock to relatives or friends (livestock songoleda in Gogo) (Swai et al., 2012; Notenbaert, Mude, Steeg \& Kinyangi, 2010).

The practice of loaning livestock to relatives or friends was undertaken as a risk aversion practice and a measure to improve livestock management for the lender; and a measure to improve life standard for the borrowers. For example, a livestock keeper from Nagulobahi village could lend a number of cattle to relatives or friends from Msisi village such that when a fatal livestock disease or rustling occurred in Nagulobahi a number of his cattle at Msisi could be safe. Conversely, individuals keeping livestock of the rich benefited from milk, manure and draught power; these advantages contributed to their effort to fight against climate change. To control diseases against livestock, men used traditional medicine for example, Azadractaindica leaves (majaniyamwarobaini) to treat livestock against ticks. In addition, they used their experience to identify livestock diseases or parasites and buy agro-chemicals from primary markets at a ward centre or from Kondoa and Dodoma towns, to treat sick animals. For the villages that had Livestock Extension Workers, for example Chipanga B, respondents consulted them for treatment when livestock were sick.

To adapt to or reduce effects of climate change on crops, women were in the front line to clear the land early in order to match with rainfall onset and reduce resources loss. Moreover, women selected and kept enough seeds for the next season, every season (Table 8). Preservation of seeds was a traditional practice that women were not required to continue observing because most of crops that were grown in the 1970s including long maturing sorghum, groundnuts and maize varieties were replaced by improved short maturing varieties. However, women continued to select and keep seeds probably because they could not afford buying improved seeds every season. Instead, women bought the amount of improved seed they could afford (for instance, one kilogram) and multiplied the seeds in the first season and then continued selecting and keeping the seeds for even five 
consecutive seasons. In addition, women used traditional substances including ashes of maize cobs and sunflower remains; and Azadractaindica leaves to treat and preserve crops including seeds every season.

Table 8. Adaptation practices undertaken to adapt or reduce climate change

\begin{tabular}{|c|c|c|c|c|}
\hline \multirow[t]{2}{*}{ Adaptation practices } & \multicolumn{2}{|c|}{ Men (n=180) } & \multicolumn{2}{|c|}{ Women $(\mathrm{n}=180)$} \\
\hline & Count & $\begin{array}{c}\text { \% of } \\
\text { responses }\end{array}$ & Count & $\begin{array}{c}\text { \% of } \\
\text { responses }\end{array}$ \\
\hline \multicolumn{5}{|l|}{$\begin{array}{l}\text { Practices undertaken to adapt or reduce effects of climate } \\
\text { change on production activities }\end{array}$} \\
\hline Feed livestock tree leaves (e.g. miyombo)/banana stems & 111 & 5.5 & 39 & 2.2 \\
\hline Livestock go without water for three days & 92 & 4.5 & 58 & 3.2 \\
\hline $\begin{array}{l}\text { Move livestock to other places/divide to friends/reduce/ fed } \\
\text { crop residues }\end{array}$ & 78 & 3.8 & 18 & 1.0 \\
\hline Use traditional herbs/experience/consult livestock officer & 69 & 3.4 & 37 & 2.0 \\
\hline Use of improved seeds/drought tolerant/short term & 176 & 8.6 & 168 & 9.3 \\
\hline Use of deep cultivation/early planting & 176 & 8.6 & 159 & 8.8 \\
\hline Use of manure & 174 & 8.5 & 115 & 6.4 \\
\hline Ask rainfall from God & 173 & 8.5 & 174 & 9.6 \\
\hline Select and keep enough seeds /replant & 166 & 8.2 & 180 & 10.0 \\
\hline Change of crop varieties/plant different dates & 154 & 7.6 & 83 & 4.6 \\
\hline Use of traditional medicine/herbs & 116 & 5.7 & 120 & 6.6 \\
\hline Early land clearing & 80 & 3.9 & 180 & 10.0 \\
\hline \multicolumn{5}{|l|}{$\begin{array}{l}\text { Practices undertaken to adapt or reduce effects of climate } \\
\text { change on environment }\end{array}$} \\
\hline Plant trees (shade/firewood) & 176 & 8.6 & 167 & 9.2 \\
\hline Contours/plant reeds (matete) & 110 & 5.4 & 94 & 5.2 \\
\hline Use of ridge farming & 113 & 5.6 & 132 & 7.3 \\
\hline Others & 72 & 3.5 & 83 & 4.6 \\
\hline Total & 2036 & 100 & 1807 & 100 \\
\hline
\end{tabular}

NB: Multiple responses.

Source: Survey data (2011).

Likewise, men were leading in using improved seeds of short maturity and drought tolerant crop varieties; undertaking deep cultivation during land preparation and planting early; using manure; and were changing crop varieties and planting crops in different dates (staggered planting). Besides, both men and women asked rainfall from God. Other adaptation practices implemented by $3.5 \%$ of men and $4.6 \%$ of women responses (Table 8 ) were intercropping; changing from food crops to cash crops; and using deep cultivation after crop emergence during first weeding, a practice that was mostly undertaken often by women. That is, instead of using deep cultivation during land preparation, women planted in the dust in order to time/match with rainfall onset and then used deep cultivation after crop emergence during first weeding to enhance water percolation. Possession of livestock and ability of men to hire tractors, power tillers or ox-carts enabled more men to secure and ferry manure to their farms compared to women. Further analysis revealed that the farms of some of men and women were located more than three kilometer away from home (64.0\% of men and $63.3 \%$ of women responses). It was not easy then for women to carry manure for such a long distance even if they were given manure by livestock keepers. Most of adaptation practices to the effects of climate change on livestock were also done by boys and girls after classes and during week-ends. The same adaptation practices were reported by Nhemachena and Hassan (2007), Ribeiro and Chaúque (2010) and Acquah and Onumah (2011).

\subsubsection{Practices Undertaken to Adapt to or Reduce Effects of Climate Change on Environment by Sex}

Other important adaptation practices undertaken in the study area were tree planting and management; contour making and reeds planting; and ridge farming (Table 8). Those practices enabled respondents to adapt to or reduce effects of floods, strong wind and whirlwind on the environment. Respondents also planted trees around 
home stead for shade, established plots of trees for firewood and other purposes; and were required to leave at least 10 trees in the field during bush clearing or plant at least 10 trees in the field to reduce wind speed (wind breaker). Tree planting and management were important practices for environmental conservation. The practices reduced possibility of wasting resources including time wasted by women to collect firewood. Moreover, contours, reeds planting and ridge farming were used to reduce water run-off and control erosion, especially in Puhi and Isusumya villages. Ridges were also used in the 1990s to trap water for crops in Kurio village because of rainfall shortage. Farmers made very big ridges which kept water in between for considerable time for crops.

It is obvious from Table 8 that men were leading in most of adaptation practices to the effects of climate change on livestock and crops production and on environment compared to women. The findings reveal that men and women responded differently to the effects of climate change on production activities and environment. The corrected Rao-Scott chi-square $\left(\chi_{c}^{2}\right)$ test showed significant association between the adaptation practices to the effects of climate change on production activities and on environment and $\operatorname{sex}\left(\chi_{c}{ }^{2}=461.323 ; p \leq 0.001\right)$, indicating that undertaken adaptation practices varied by sex of respondent. The difference could probably be explained by the variation in roles; unequal access to assets and benefits accrued from production; unequal control of household assets; and other opportunities. For example, it was revealed during focus group discussions that other men trained oxen of the rich farmers in order to use the animals for land preparation; and a number of men assisted oxen owners during land preparation in order to secure oxen service. These were among the opportunities that women could not access. Adaptation practices to the effects of climate change on production activities and environment were important for respondents to increase yield, number of livestock including an increase in milk production; reduce food shortage or hunger and an increase in income. If the income of respondents is increased, their status and ability to meet household development targets will subsequently improve.

\subsection{Elements Influencing Adaptation Practices}

Findings in Table 9 reveal that the effort of women to adapt to or reduce effects of climate change was mainly obstructed by various elements including inadequate capital and limited access to credit, use of poor production tools and having small farms. Conversely, the effort of men to adapt to or reduce effects of climate change was mainly obstructed by inadequate input and veterinary services including cattle dip facility in the study area; inadequate manpower, sickness and old age; inadequate formal markets; and inadequate knowledge of improved crops and livestock production (Nhemachena \& Hassan, 2007; Deressa et al., 2008).

Table 9. Elements influencing adaptation practices

\begin{tabular}{lcccc}
\hline Description & \multicolumn{2}{c}{ Men (n=180) } & \multicolumn{2}{c}{ Women (n=180) } \\
& $\mathbf{n}$ & $\mathbf{\%}$ & $\mathbf{n}$ & $\mathbf{\%}$ \\
\hline Elements impeding adaptation & 36 & 20.0 & 47 & 26.1 \\
Inadequate capital including credit & 35 & 19.4 & 28 & 15.6 \\
Inadequate input and veterinary services & 32 & 17.8 & 37 & 20.6 \\
Inadequate production tools & 24 & 13.3 & 13 & 7.2 \\
Inadequate manpower, sickness and old age & 20 & 11.1 & 8 & 4.4 \\
Inadequate formal market & 19 & 10.6 & 16 & 8.9 \\
Inadequate improved production knowledge & 14 & 7.8 & 31 & 17.2 \\
Small farms & $\mathbf{1 8 0}$ & $\mathbf{1 0 0 . 0}$ & $\mathbf{1 8 0}$ & $\mathbf{1 0 0 . 0}$ \\
Total & & & & \\
Elements facilitating adaptation & 53 & 29.4 & 40 & 22.2 \\
Improved transport, communication and business & 46 & 25.6 & 47 & 26.1 \\
Patience and ability to work hard & 40 & 22.2 & 28 & 15.6 \\
$\begin{array}{l}\text { Observation of government bye-laws and directives } \\
\text { Mutual support spirit and ability to learn from }\end{array}$ & 24 & 13.3 & 43 & 23.9 \\
others & 17 & 9.4 & 22 & 12.2 \\
Involvement in non-farm production activities & $\mathbf{1 8 0}$ & $\mathbf{1 0 0 . 0}$ & $\mathbf{1 8 0}$ & $\mathbf{1 0 0 . 0}$ \\
Total & & & & \\
\hline
\end{tabular}

Source: Survey data (2011). 
Besides, practices of women to adapt or reduce effects of climate change were facilitated by the ability of women to work together and to learn from other farmers; and their ability to be involved in non-farm production activities. For the men, improved transport, communication and increased business; together with the ability to observe government by-laws and directives facilitated their adaptation practices. Moreover, both men and women were patient and hard working.

In the study area, men and women had ability to work together under mutual support where one household prepared food and invited friends or neighbours (kualikana in Swahili or kularika in Kirangi) to assist them during land tillage, weeding or harvesting operations. This practice reduced the problem of inadequate manpower and shortage of cash for paying hired labour. In addition, in the 1990s in all surveyed villages, transport, transport means including buses, motorcycles and bicycles; and communication had improved in comparison to the 1970s. These enabled business men from Kondoa or Dodoma towns to transport various food items to the study area during food shortage; and also the situation facilitated exchange of various commodities either for money or food. For example, in Nagulobahi village respondents exchanged paddy for sorghum or pearl millet and businessmen came straight to the village to buy paddy. That action reduced cost of transporting food items to the ward centre or Dodoma Town. Likewise, villages had established various by-laws and regulations that farmers were required to observe. For example, every farmer was required to use farm yard manure; and farmers were not allowed to cut trees even if they were the owners of those particular trees, without seeking permission from the village government.

\section{Recommendations}

The study recommends systematic collection of in-depth information on climate change and gender at the community level in other areas of Dodoma Region, Tanzania and the Least Developed Countries (LDCs), in order to obtain enough disaggregated information. This will avail more and diverse location specific climate change indicators from the study areas and enable the policy makers on climate change to design and implement appropriate interventions to manage climate change problems. More studies on climate change and various locations/villages; ethnic groups and married and single individuals are important in order to generate more generalized conclusions. The study also suggests that, adaptation practices undertaken by respondents can be learned through their roles in the household and/or community. Moreover, the study calls for appropriate stakeholders including the Local Government Authorities (LGAs); Agriculture and Livestock sectors; the Central Government of Tanzania, Non-governmental Organizations (NGOs) and other development practitioners to provide farmers with necessary inputs and credit services in order to improve their adaptive capacity.

\section{Conclusion}

The majority of men and women perceived climate change (increased rainfall variation, temperature, strong wind and drought) and managed to identify adaptation practices undertaken to manage climate change effects; and elements impeding/facilitating adaptation practices. The information obtained can be used to improve/formulate appropriate adaptation practices to manage climate change problems in the Agriculture and Livestock sectors. However, respondents perceived and adapted differently to the effects of climate change depending on sex, location/village, marital status and ethnic groups. This implies that location/village, marital status and ethnic groups are also important variables in climate change studies, especially when characteristic of the effects of climate change of being location specific is taken into account. Adaptation practices undertaken by respondents were biased towards their roles. Women were more devoted to the measures of adaptation that enabled them to adapt to or reduce effects of climate change during hunger/food, water and firewood shortages and men were more devoted to the adaptation measures that enabled them to adapt to or reduce effects of climate change on crops, livestock and environment. This implies that adaptation practices undertaken by respondents to adapt to or reduce effects of climate change can be learned through their roles. However, the effort of respondents to adapt to or reduce effects of climate change was obstructed by various elements including inadequate production tools, inputs, capital, knowledge on improved production, formal markets, veterinary and credit services. If the identified obstacles to production will be corrected the adaptive capacity of respondents will improved and both men and women will be in a better position to manage climate change problems.

\section{References}

Acquah, H., \& Onumah, E. E. (2011). Farmers Perception and Adaptation to Climate Change: An Estimation of Willingness to Pay. Agris on-line Papers in Economics and Informatics (Number 4, pp. 39).

Agrawal, A., McSweeney., C., \& Perrin, N. (2008). The Role of Local Institutions in Adaptation to Climate Change. Paper prepared for the Social Dimensions of Climate Change (p. 65). Social Development Department, the World Bank, Washington DC. 
Agwu, J., \& Okhimamhe, A. (2009). Gender and climate change in Nigeria: A study of four communities in North-central and South-eastern Nigeria. Heinrich BöllStiftung (HBS) (p. 70).

Brody, A., Demetriades, J., \& Esplen, E. (2008). Gender and climate change: Mapping the linkages, a scoping study on knowledge and gaps, Institute of Development Studies (IDS), UK, BRIDGE.

Chaudhary, P., \& Aryal, K. P. (2009). Global Warming in Nepal. Challenges and Policy Imperatives. Journals of Forest and Livelihood, 8(1), 5 - 14.

Cline, W. R. (2007). Global warming and agriculture. Impact estimates by country. Washington DC, Centre for Global Development and the Peterson Institute for International Economics.

Deressa, T., Hassan, R. M., Alemu, T., Yesuf, M., \& Ringler, C. (2008). Adaptation Methods and Perceptions of Climate Change in the Nile Basin of Ethiopia. Environment and Production Technology Division IFPRI Discussion Paper, 00798, 26.

Ehrhart, C., \& Twena, M. (2006). Climate Change and Poverty in Tanzania realities and response options for CARE. Background report CARE International Poverty-Climate Change Initiative (p. 30).

FAO. (2008). Climate change adaptation and mitigation in the Food and Agriculture sector technical background document from the expert consultation held on 5 to 7 March 2008 FAO, Rome (p. 16).

Haque, A., Yamamoto, S., Malik, A., \& Sauerborn, R. (2012). Households' perception of climate change and human health risks: A community perspective. Environmental Health, 11(1), 12. http://dx.doi.org/10.1186/1476-069X-11-1

IPCC. (2007). Summary for Policy makers. In: Climate Change 2007: Impacts, Adaptation and Vulnerability. Contribution of Working Group II to the Fourth Assessment Report of the Intergovernmental Panel on Climate Change, Cambridge.

Ishaya, S., \& Abaje, I. (2008). Indigenous people's perception on climate change and adaptation strategies in Jema'a local government area of Kaduna State, Nigeria. Journal of Geography and Regional Planning, 1(8), 138-143.

Jotoafrika. (2011). Adapting to climate change in Africa. Women as key players in climate adaptation, 6. Retrieved March 2011, from http://www.eldis.org/vfile/upload/1/document/1104/JotoAfrika_Issue206.pdf

Kapoor, A. (2011). Engendering the Climate for Change Policies and practices for gender-just adaptation. Alternative Futures and Heinrich BÖll Foundation (HBF) (p. 64).

Kayunze, K. A. (2000). Poverty disparities in small, large and male headed households in rural Tanzania: A case study of Mbeya Region. Tanzanian Journal of Population and Development Studies, 7(1\& 2), 1-16.

Lambrou, Y., \& Piana, G. (2006). Gender: The missing component of the response to climate change, Food and Agriculture Organization of the United Nations Rome (p. 58). Retrieved from http://www.fao.org/sd/dim_pe1/docs/pe1_051001d1_en.pdf] on 12/04/2012

Lavassani, K., Movahedi, B., \& Kumar, V. (2009). Developments in analysis of multiple response survey data in categorical data analysis: The case of enterprise system implementation in large North American firms. Journal of applied quantitative methods (JAQM), 4(1/4), 53. Retrieved Spring 2009, from http://jaqm.ro/issues/volume-4,issue-1/pdfs/lavassani_movahedi_kumar.pdf on 18/06/2012

Lema, M., \& Majule, A. (2009). Impacts of climate change, variability and adaptation strategies on agriculture in semi arid areas of Tanzania: The case of Manyoni District in Singida Region, Tanzania. African Journal of Environmental Science and Technology, 3(8), 206-218.

Maddison, D. (2006). The perception of and adaptation to climate change in Africa. Discussion Paper Series No. 10. Centre for Environmental Economics and Policy in Africa (CEEPA).

Maharjan, S. K., Sigdel, E. R., Sthapit, B. R., \& Regmi, B. R. (2011). Tharu community's perception on climate changes and their adaptive initiations to withstand its impacts in Western Terai of Nepal. International NGO Journal, 6(2), 035-042.

Marshall, N. A., \& Marshall, P. A. (2007). Conceptualizing and Operationalizing Social Resilience within Commercial Fisheries in Northern Australia. Ecology and Society, 12(1), 1-14.

Mengistu, D. K. (2011). Farmers' perception and knowledge of climate change and their coping strategies to the related hazards: Case study from Adiha, central Tigray, Ethiopia. International NGO Journal, 2(2), 138-145. 
Mongi, H., Majule, A. E., \& Lyimo, J. G. (2010). Vulnerability and adaptation of rain fed agriculture to climate change and variability in semi-arid Tanzania. African Journal of Environmental Science and Technology, 4(6), 371-381.

Mutekwa, V. T. (2009). Climate change impacts and adaptation in the agricultural sector: the case of smallholder farmers in Zimbabwe. Journal of Sustainable Development in Africa, 11(2), 237-256.

Nature International weekly journal of science. (2011). Different method, same result: Global warming is real. Retrieved October 20, 2011, from http://www.nature.com/news/2011/111020/full/news.2011.607.html

Nelson, V., \& Stathers,T. (2009). Resilience, power, culture, and climate: a case study from semi-arid Tanzania, and new research directions. Gender and Development, $17(1), 81$ - 94. http://dx.doi.org/10.1080/13552070802696946

Nhemachena, C., \& Hassan, R. (2007). Micro-Level Analysis of Farmers' Adaptation to Climate Change in Southern Africa Environment and Production Technology. IFPRI Discussion Paper, 00714, 30.

Notenbaert, A., Mude, A., Steeg, J., \& Kinyangi, J. (2010). Options for adapting to climate change in livestock dominated farming systems in the greater horn of Africa. Journal of Geography and Regional Planning, 3(9), 234-239.

Odjugo, P. A. O. (2010). Adaptation to Climate Change in the Agricultural Sector in the Semi-arid Region of Nigeria, $2^{\text {nd }}$ International Conference: Climate, Sustainability and Development in Semi-arid Regions, Fortaleza - Ceará, Brazil.

Osman-Elasha, B. (2008). Gender and Climate Change in the Arab Region. Arab Women Organization (p. 44). Retrieved March 15, 2010, from http://www.arab-hdr.org/publications/other/ahdrps/paper02-en.pdf

Paavola, J. (2008). Livelihoods, vulnerability and adaptation to climate change in Morogoro, Tanzania. Sustainability Research Institute (SRI), School of Earth and Environment, University of Leeds, Leeds LS2 9JT, UK (pp 642-654).

Prahalad, C. K. (2009). To focus on sustainable development is a way to nurture the bottom line in every business. Posted in Business, COP15. Sustainable Development. Retrieved December 15, from http://educationforsustainabledevelopment.com/blog/?p=91 on 16/02/2012

Ribeiro, N., \& Chaúque, A. (2010). Gender and Climate change: Mozambique Case Study. Heinrich Böll Foundation Southern Africa (p. 42).

Swai, O. W., Mbwambo, J. S., \& Magayane, F. T. (2012). Perceived Effects of Climate Change on Agricultural Production: A Gendered Analysis Done in Bahi and Kondoa Districts, Dodoma Region, Tanzania. Research on Humanities and Social Sciences, 2(9), 59 - 68.

Tanzania Human Development Report. (2000). The State of Progress in HumanResource Development 1999 (p. $65)$.

UNDP. (2009). Resource guide on gender and climate change, United Nations Development Programme, Printing: A. K. Office Supplies, Ltd (p.133).

UNFCCC. (2007). Climate change: Impacts, vulnerabilities and adaptation in developing countries UNFCCC (p. 64).

UNFPA. (2009). State of world population report. Facing a changing world: Women, Population and Climate. The United Nations Environment Programme. Worldwatch Institute (p. 94).

URT. (2007). National Adaptation Programme of Action (NAPA); Vice President's Office, Division of Environment, January 2007, p. 52.

URT. (2003). Dodoma Region Socio-economic Profile. Government Printer Dar es Salaam Tanzania (p. 219).

URT. (2002). Household Budget Survey 2000/01. Final Report National Bureau of Statistics Tanzania. Colour printing Dar es salaam Tanzania Limited.

WWF. (2006). Climate Change Impacts on East Africa (p. 12). A Review of the Scientific Literature, World Wide Fund for Nature (formerly World Wildlife Fund), Gland, Switzerland.

Yanda, P., Kangalawe, R., \& Sigalla, R. (2006). Climate and Socioeconomic Influence on Malaria and Cholera Risks in the Lake Victoria Region of Tanzania. Environmental Economics, IV(3), 44 -70. ICFAI. 